\title{
Journal of Architectural Conservation

\section{Rural carob warehouses in Cyprus: an assessment of architectural and structural characteristics}

\section{Beser Oktay Vehbi, Hülya Yuceer \& Yonca Hurol}

To cite this article: Beser Oktay Vehbi, Hülya Yuceer \& Yonca Hurol (2016) Rural carob warehouses in Cyprus: an assessment of architectural and structural characteristics, Journal of Architectural Conservation, 22:1, 18-47, DOI: 10.1080/13556207.2016.1208473

To link to this article: http://dx.doi.org/10.1080/13556207.2016.1208473

\section{Published online: 05 Aug 2016.}

\section{Submit your article to this journal $\sqsubset$}

Џ Article views: 51

Q View related articles $\sqsubset$

View Crossmark data ¿ 


\title{
Rural carob warehouses in Cyprus: an assessment of architectural and structural characteristics
}

\author{
Beser Oktay Vehbi ${ }^{a}$, Hülya Yuceer ${ }^{b}$ and Yonca Hurol ${ }^{a}$ \\ ${ }^{a}$ Department of Architecture, Eastern Mediterranean University, Famagusta, Northern Cyprus, Turkey; \\ ${ }^{\mathrm{b}}$ Department of Architecture, Adana Science and Technology University, Adana, Seyhan, Turkey
}

\begin{abstract}
Carob warehouses in the rural areas of Cyprus constitute one of the rare examples of traditional industrial building types that are evidence of a vanishing tradition of agricultural, social and economic life. These warehouses were built in the late nineteenth and early twentieth centuries, and used as part of the carob production and export industry that showed a drastic decline after 1960 and virtually vanished in the following decade, resulting in the dereliction of the warehouses. Today, very few of them are in good condition, some have disappeared, and many are left with major structural damage or have been partially destroyed. In order to contribute to their protection and to add to the existing literature on industrial buildings in rural areas, the present work aims to examine the architectural and structural characteristics of rural carob warehouses in Cyprus. The assessments are based on a model formed through observations noted during the field survey in the northern section of the island where 15 carob warehouses are located mainly on the coast. The model of architectural and structural features of the warehouses includes the recording of alterations, material deterioration and structural damage. The study concludes with an overall approach for the restoration and consolidation of the warehouses employing techniques that follow the principles of international charters. Suggestions are given for promoting the potential of these heritage assets and enabling assessment of their general reuse potentials. It is found that among the 15 existing warehouses three of them have already been restored and the other 12 require restoration.
\end{abstract}

\section{KEYWORDS}

Carob warehouse; architectural heritage; architectural assessment; structural assessment; holistic conservation approach; Cyprus

\section{Introduction}

Being modest in their design and structure, rural buildings such as carob warehouses may not attract the same attention as urban monumental buildings, yet they constitute a significant place in rural landscapes.

Traditional industrial buildings in rural areas have been addressed by few studies. ${ }^{1}$ There is only one recently published article in an international journal that relates to the carob warehouses of Cyprus and their adaptive reuse potentials. ${ }^{2}$ However, this study considers the existing rural industrial buildings in Cyprus to be significant heritage sites that justify more research. 
The island of Cyprus, where the warehouses exist, is located in the eastern part of the Mediterranean Sea. Due to its position it was reigned over by several civilizations over the centuries. Current heritage sites are mainly from the Lusignan, Venetian, Ottoman and British periods. ${ }^{3}$ The carob warehouses are from the British period, which began in 1868 and ended with the island's independence in 1960. In 1974, the island was divided into two sectors - the southern part where the Greek Cypriot community live and the northern part where the Turkish Cypriot community live. This division still exists on the island.

The carob warehouses are distributed throughout Cyprus, mostly along the coast. The main region for carob cultivation in the northern part of the island stretches from Morphou in the east, to Kyrenia and the Karpas in the west.

In the past, most of the population lived in rural areas where everyday life and the economy were based on agriculture, and where carob harvesting and processing formed a significant part of this production. The lack of roads, railways and harbours was a major factor for the construction of carob warehouses to store the carob harvests. Famagusta harbour was completed in 1906 and the Cyprus railway, which connected Famagusta, Nicosia and Morphou, was opened in 1907. ${ }^{4}$ However, these developments were not enough to ensure the efficient transportation of all the carob as many of the plantations are located on the northern coast separated by the Kyrenia Five Finger Mountains lying parallel to the shore line ${ }^{5}$ The British government therefore constructed the warehouses to allow the carob to be stored prior to being transferred to ships via adjoining jetties.

There is little evidence about the construction period of most of the carob warehouses. As stated by Bagiskan, carob warehouses with harbours were identified as Paphos, Gemikonagi, Vassilia, Larnaca, Famagusta, Kyrenia, Limassol and Akanthou by one of the administrators of the British police department on 27 May 1898. ${ }^{6}$ The only evidence that was observed during the site survey, were the dates provided on the door frames of some of the warehouses as 1905, 1909 and 1930.

After World War II, the rural warehouses lost their importance for two main reasons; one was that the migration of rural people to urban centres decreased carob harvesting and the second was the construction of the urban warehouses in 1940.

The establishment of the independent Cyprus Government in 1960, which caused a gradual release in the presence of British capital in Cyprus, had another impact on the export and trade activities which had also affected the use of rural warehouses.

Carob warehouses are single storey, wide span, rectangular stone masonry buildings (Figure 1). The sites for the construction of the warehouses were often at a steep gradient which allowed easy access for loading the bags of carob into the warehouses from the back and then transferring them to the north façade onto the ships via a wooden jetty (Figure 2).

These warehouses are considered to be significant heritage sites of the Cyprus rural landscape. They deserve more attention, since they represent both the past agricultural activities and the carob shipping ways for export.

This article focuses on the architectural and structural characteristics of the warehouses to enable assessment of their reuse potential. Material and structural damage analyses have been carried out to identify the most common problems, and recommendations have been made to address these. 


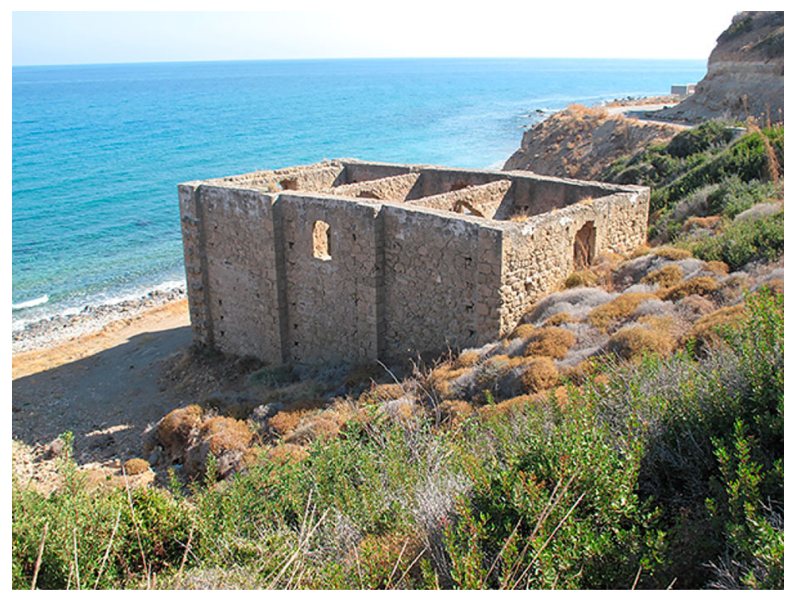

Figure 1. Carob Warehouse in Esentepe village (Photo by Beser Oktay Vehbi).

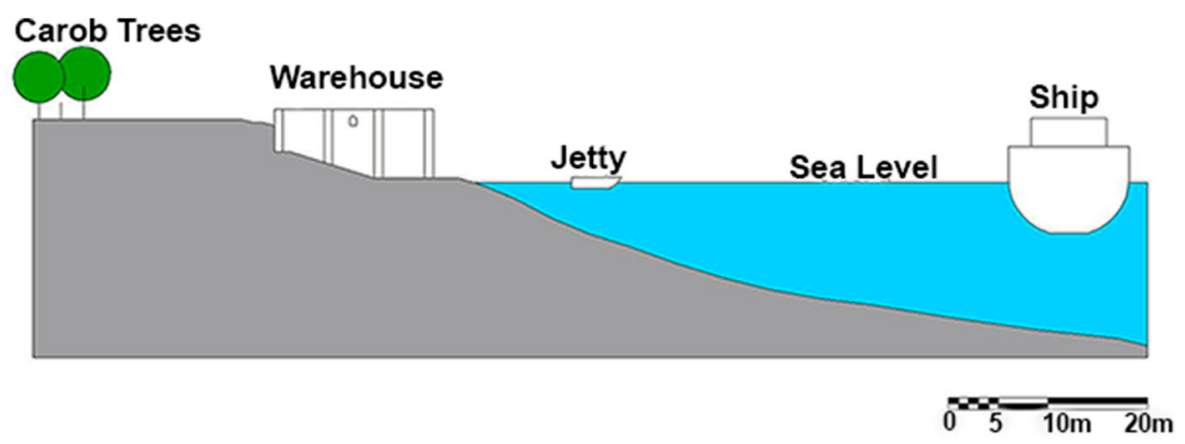

Figure 2. Transport of carob harvest from the warehouse to cargo-ship (Drawn by Hulya Yuceer).

The study was carried out in the coastal areas of the northern part of Cyprus, and primarily based on the findings of a field survey in that area. An overall research was for about 53 existing carob warehouses throughout the island. This study focused on the examples that are found in rural areas, since their architectural and structural characteristics present some differences to the 18 warehouses in urban areas. Seventeen rural warehouses located on the northern part of the island were selected for detailed examination (see Figure 3), although two of these have been totally destroyed. Among the 15 existing warehouses three of them have already been restored. Material deterioration due to being close to the sea, abandonment and inappropriate alterations are the major causes of the structural damage in the 12 warehouses. Six of the 12 warehouses need total reconstruction because of serious structural damage and other six should be restored urgently due to their minor and/or major material deteriorations.

The 18 warehouses on the south side of Cyprus have to be studied separately because of the higher earthquake risk there. ${ }^{7}$ 


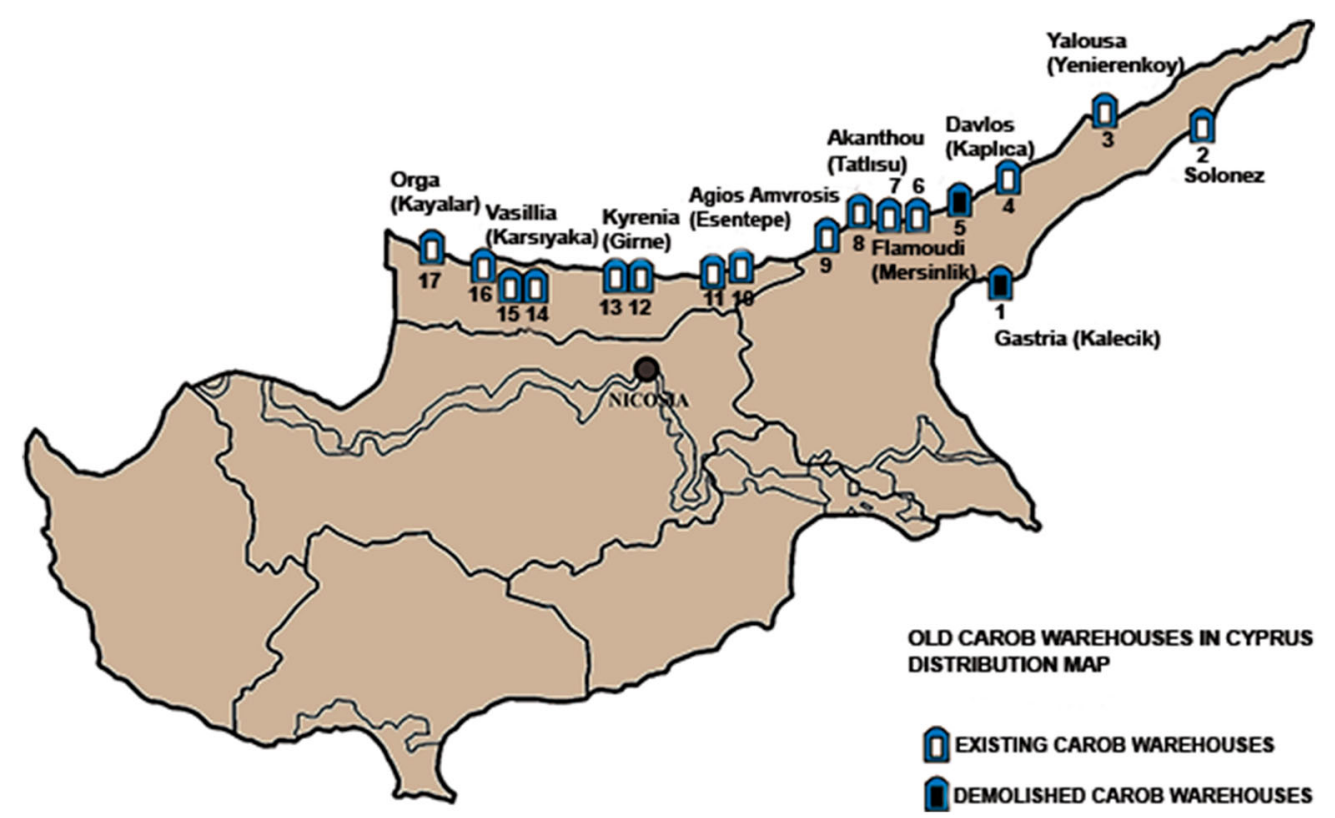

Figure 3. Location map of carob warehouses in north Cyprus (Drawn by Hulya Yuceer).

The outline of this study is structured under the following main topics:

- Methodology

- The fieldwork results

- Suggestions for a holistic conservation

- Case study: Kayalar warehouse

- Conclusion.

\section{Methodology}

There is a lack of information about carob warehouses. The existing inventory charts of the 12 warehouses that are available in the Department of Antiquities provide very limited information. In order to create the historical background for the warehouses, a historical survey was carried out by examining written sources, archives, statistical documents, maps and old pictures. These dated back from the British period and include Blue Books and a British Admiralty Map dating from $1936 .^{8}$ The letters and published works of travellers, the works of local authors and old newspapers were also examined.

A field survey was carried out by five architects, two of whom are specialists in conservation and one has expertise on structure. The findings of this research are based on a sixyear study undertaken between 2010 and 2016.

The field survey was completed in the following stages:

- A tour around the whole island to mark the warehouses on the map. 
- A team of five people prepared the inventory forms of warehouses between September 2010 and March 2011. During this process the people formerly involved with these buildings such as the owners, past workers and security guards were interviewed.

- All of the warehouses were revisited in 2016 in order to determine the level of structural and material damage and the recent conservation activities.

- Finally, the data was analysed with the help of a four-dimensional model containing the following information:

-Architectural features including structural system and construction techniques

-Alteration time and type

-Structural damage

-Material deterioration

Tables containing matrices of various combinations of this model identified the patterns of damage and their reasons. These results assisted in determining the solutions to various types of damage and the precautions to be taken.

\section{Fieldwork results}

The fieldwork sets out the environmental relations, topography usage, plan types, architectural elements and alterations.

\subsection{Architectural features}

Architectural features of the warehouses are presented under the following sub-headings:

(1) Site, setting and ownership

(2) Space characteristics and plan layout

(3) Building elements including structural elements.

\subsubsection{Site, setting and ownership}

The storage buildings for the harvested carob were constructed close to both the carob fields and the natural harbour locations. Since they were built away from the new traffic lanes, about five to 10 meters away from the sea, it is very hard to access them by car. Among the 15 warehouses, 13 of them are located on an inclined site near the sea (three of these are in a village), one on the mountain and one located $1 \mathrm{~km}$ away from the sea.

The climatic conditions were also taken into consideration in locating the warehouses. They all face the prevailing winds to create airflow through the building to reduce the effect of moisture and humidity damaging the carob.

Regarding the legal status and ownership of the 17 warehouses, five of them (including the two totally destroyed warehouses) are under the control of the Evkaf Foundation (established after the Ottoman conquest of the island, as a holy foundation which since then has collected properties appropriated for religious and charitable uses) and they are all registered; nine of them are owned and listed by the Department of Antiquities 
Table 1. Status of registration, ownership and current use.

\begin{tabular}{lllcl}
\hline No & Type of statue & \multicolumn{1}{c}{ Ownership } & Number & \multicolumn{1}{c}{ Current Use } \\
\hline 1 & Registered & $\begin{array}{c}\text { Department of } \\
\text { Antiquities } \\
\text { Evkaf Foundation }\end{array}$ & 9 & 6 Abandoned, museum, restaurant and hotel \\
2 & $\begin{array}{c}\text { Non- } \\
\text { Registered }\end{array}$ & Private & $\begin{array}{c}3+2 \\
\text { (destroyed) } \\
3\end{array}$ & $\begin{array}{l}2 \text { Abandoned } \\
1 \text { Therapy centre (currently not in use) } \\
\text { 2 Residential (one in use, one abandoned) and } \\
\text { abandoned hotel }\end{array}$ \\
Total & & 15 & \\
\hline
\end{tabular}

and three have private owners. Warehouses that have private ownership are not registered. Eight registered warehouses are currently vacant. Another four that are registered have been converted to a restaurant, museum, hotel and therapy center and the three unregistered ones were changed to have residential and hotel uses (Table 1).

\subsubsection{Space characteristics and plan layout}

The warehouses can be categorized into two types according to the organization of their spaces: (Figures 4 and 5)

- Single-storey rectangular buildings with single space and flat roof

- Single-storey rectangular buildings with multiple spaces and flat roof.
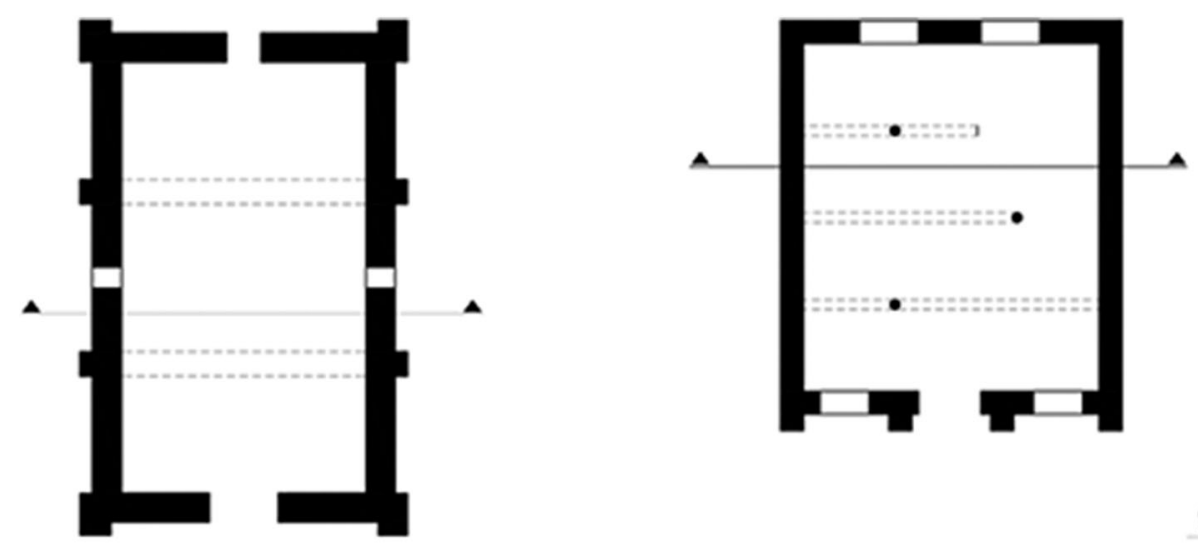

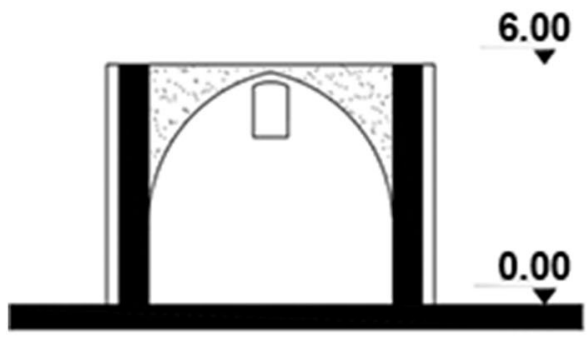

Esentepe 1
9.20

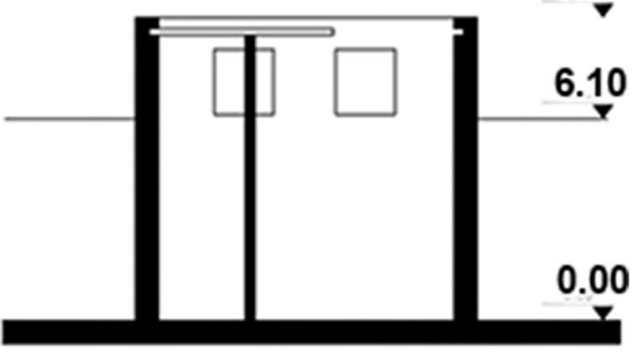

Tatlısu 1

Figure 4. Some carob warehouses with single unit (Drawn by Sanaz Nezhadmasoum and Beser Oktay Vehbi). 

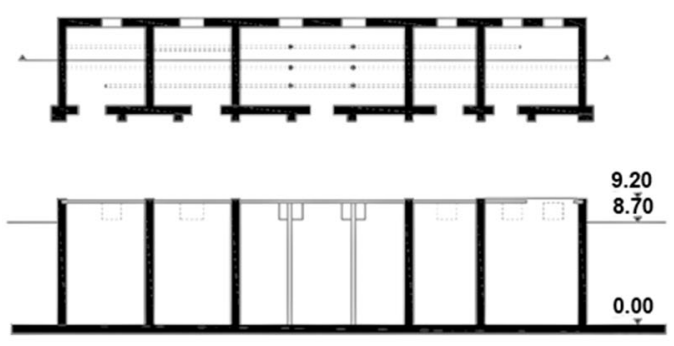

Tatlısu 2

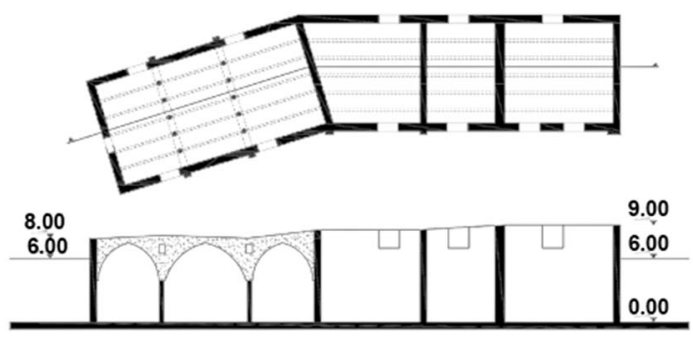

Yenierenkoy
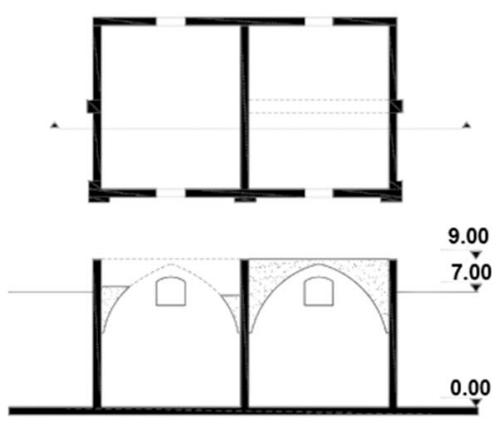

Kayalar
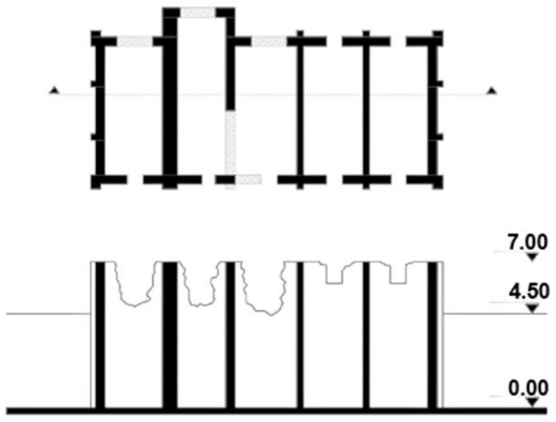

Esentepe 2

Figure 5. Some carob warehouses with multiple units (Drawn by Sanaz Nezhadmasoum and Beser Oktay Vehbi).

Due to the alterations in some of the warehouses, two further categories were identified (Table 2):

- Originally single-storey, single space with second floor as a vertical annex

- Originally single-storey, multiple spaces with second floor as a vertical annex.

There is no access from one room to the other in the multiple space warehouses. Some warehouses lost their architectural character due to having a second floor addition as a vertical annex. These are all in the same village (Karşıyaka).

\subsubsection{Building elements}

Stone walls, roof structure, doors, windows and floor surfaces are the main building elements of carob warehouses.

Table 2. Basic types of warehouses.

\begin{tabular}{llc}
\hline No & \multicolumn{1}{c}{ Architectural typology } & Number \\
\hline 1 & Single-storey with single space & 3 \\
2 & Single-storey with multiple spaces & 8 \\
3 & Originally single-storey, single space with second floor & 1 \\
4 & Originally single-storey, multiple space with second floor & 1 \\
Total & & 15 \\
\hline
\end{tabular}


3.1.3.1. Stone walls. All warehouses are constructed using a stone masonry system with local yellow sandstone walls that are $40-50 \mathrm{~cm}$ thick. These buildings had very few openings with regular buttresses and are clearly identifiable from the sea. Since the south walls of these buildings rest on the rocks, their height appears lower from that direction. Thus these heavy stone structures are rather hidden when they are approached from the land.

The distance between two walls are either four or eight meters for small spans, but it can also be approximately 20 meters for longer spans. The height of the walls can be eight or nine meters. Larger warehouses contain other structures in them, such as arches or timber posts.

The walls of each warehouse have different arrangements of the stone rubble which represents the individuality of the mason. The stones of eight of the warehouses are well-cut, equal and laid in regular, horizontal courses. For seven others different stone sizes are used in a more random arrangement. The mixture of yellow stone powder and cement were used as mortar for both the external and internal faces of some warehouses, which were recently restored.

The walls are supported by buttresses of 70-90 cm in width from the north, east and west directions in order to support the structure against horizontal forces. On the south side the buildings rest on rock, and do not require buttresses. Since the span between the two walls and the free standing height of the walls are extraordinary for masonry structures, the wall thickness of warehouses with longer spans are too small. Corner buttresses are wider at the base of four of the warehouses. The others are the same size throughout their height. Seven warehouses have buttresses rising up to the top of the buildings, four warehouses have buttresses rising up to $2 / 3$ of the height and one warehouse has buttresses rising up to $4 / 5$ of its height.

The interior walls of five of the warehouses that have multiple rooms were built with earth mortar unlike their exterior walls, which were built with cement mortar. This was probably for economic reasons and limited availability, which resulted in the use of cement only for the exterior walls.

The exterior walls have limited openings and some small holes for ventilation. Stone details of different size and texture are used in distinctive styles around the openings of these building.

3.1.3.2. Roof structure. The flat roofs were constructed from timber and tree branches, straw and compacted earth. This is a traditional type of construction in Cyprus that according to local residents comprises four separate layers. ${ }^{9}$ The first layer is the timber beams sourced from local Cypress trees. The small branches of this tree cover these beams as a second layer. Over these branches straw is placed as the third layer. Earth is the last layer of these flat roofs.

Warehouses contain four different structural roof systems: (Table 3).

- Timber and steel beams resting on stone walls and timber beams carrying the roof.

- Timber beams, which are carried by timber posts which are made out of Cypress trees. Pieces were added to the beams to achieve longer spans. These beams were supported with columns from the points of addition.

- One bay stone pointed arch, which supports the timber beams.

- Multiple arches which are supported by stone posts inside and by walls outside. 
Table 3. Variations of the roof structures among the warehouses (Photos by Beser Oktay Vehbi).

\begin{tabular}{ll} 
Roof Structure & Number of \\
\hline Timber and steel beam &
\end{tabular}

Photo
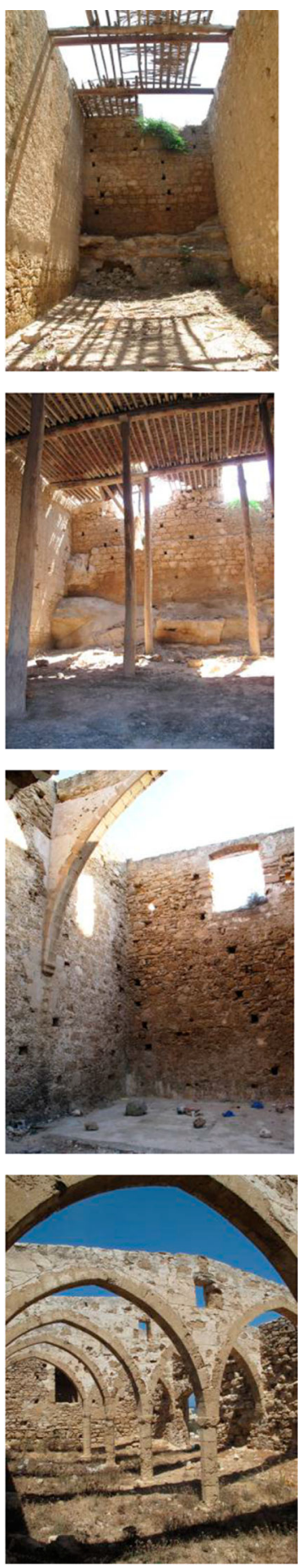
The stone arches of these buildings span eight meters and the timber beams span nine meters. Some warehouses combine various sizes of spaces and various types of roof structures for the different spaces within. This increases the number of types of roof structures and warehouses.

3.1.3.3. Doors. The doors of the warehouses are oriented towards the sea. Most of the single and the multiple unit warehouses originally have arch formed doors, but a few of them have rectangular forms. The rectangular door types are on the buildings with alterations. Three of the warehouses keep both arch and rectangular formed doors, four of them only have rectangular doors.

The dimensions of the doors are generally the same $(2.5 \mathrm{~m} \times 2 \mathrm{~m})$. Due to the alterations of the warehouses, three different types of lintels were observed: the first one that is original, is a small cut-stone frame within an arch form, the second and the third ones are straight timber and rectangular slab stone that were used for the rectangular formed doors (Table 4).

Only three examples still retain their original timber doors with iron fixtures and locks. Six of the warehouses retain their original door forms. Seven of them have been changed from arched to rectangular doors.

3.1.3.4. Windows. All of the warehouses have different numbers of windows with different dimensions. They are only located on the north and south façades. Windows on the north

Table 4. Basic door shape and lintel type among the warehouses (Photos by Beser Oktay Vehbi).

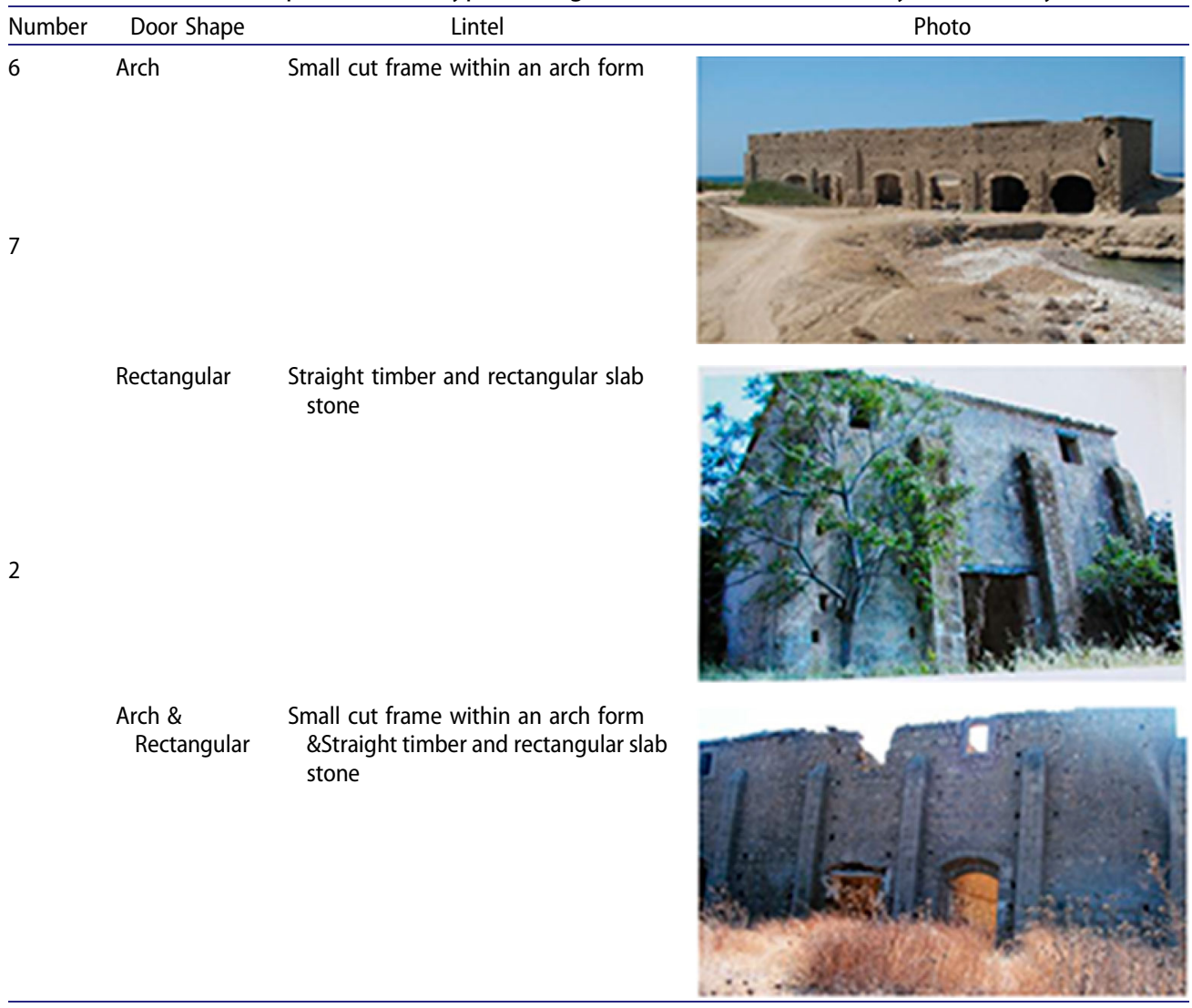




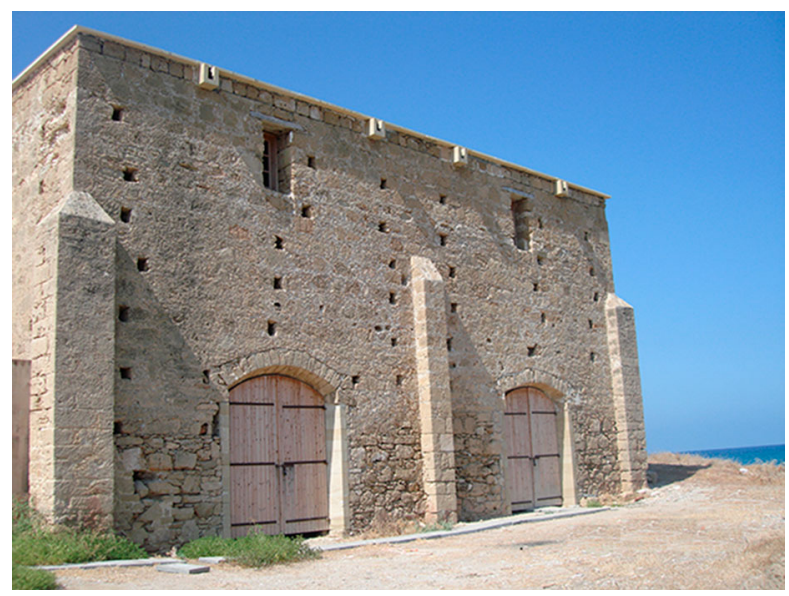

Figure 6. Small holes on the façade (Mersinlik 1) (Photo by Beser Oktay Vehbi).

facade are close to the ceiling and small in size. The number of windows on the front elevations varied depending on the size of the warehouse. Each rectangular unit has at least one top window on the north side which is $40 \times 60 \mathrm{~cm}$. All of the southern windows are $80 \times 120 \mathrm{~cm}$ and they were used to load the carob into the building. Some warehouses have arch formed windows with small cut stone frames, some have timber and stone lintels for rectangular windows.

Openings have wooden shutters and metal bars fixed into the stonework. Currently a few of the well-restored examples have their wooden shutters and steel bars.

Furthermore, the small ventilation holes (Figure 6) no longer exist in six of the warehouses, which have been adapted or restored.

3.1.3.5. Floor surfaces. Most warehouses have a rubble stone floor but some had larger yellow stone flags. There are a few warehouses that have compacted soil as the floor covering (Figure 7). The contemporary floor coverings like marble and timber parquet are only found in the warehouses that were adapted later.

\subsection{Alterations}

Alterations which were made to carob warehouses can be analysed under two headings:

- Time of alteration

- Type of alteration.

\subsubsection{Time of alteration}

There were four different times in which alterations were done:

- Old alterations that were done during the British period

- New alterations that were done after the British period 


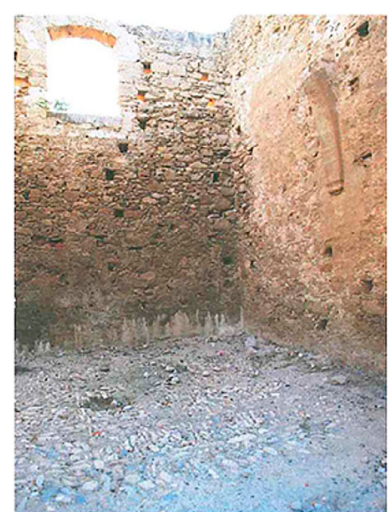

Rubble stone floor

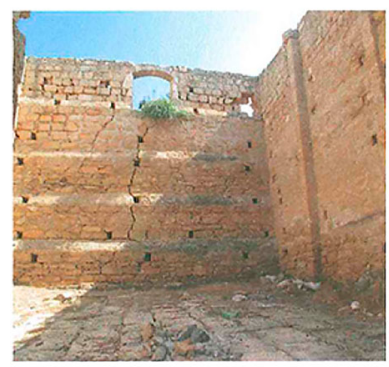

Yellow stone floor

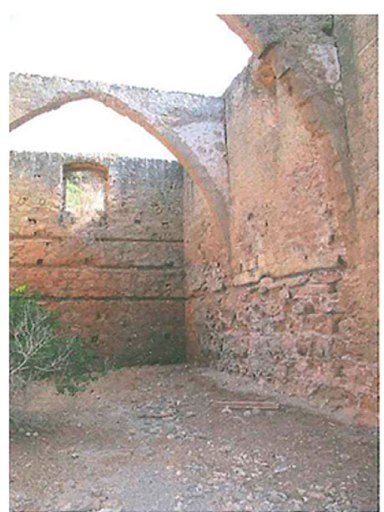

Compacted Soil floor

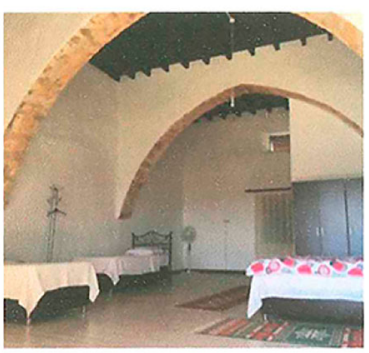

Timber parquet floor

Figure 7. Different type of floor covers (Photos by Beser Oktay Vehbi).

- Alterations done both during and after the British period

- None.

The number of buildings that had these alterations can be seen in Table 5 .

\subsubsection{Type of alterations}

Type of alterations made to warehouses can be listed as:

- Making various changes to openings

- Additions of space (rooms, floors, mezzanine floors)

- Additions of elements (reinforced concrete roofs, timber lintels, balconies, staircases, etc.)

- Changing location of interior walls

- Closing small holes

- Retrofitting (increasing thickness of retaining walls, injecting grout into walls)

- Cut stone decorations at corners and around openings

- Raising the ground level.

The first five alterations are more common than the others. Some of these alterations damaged the architectural character of the building, such as the Karşiyaka-house (Figure 8), whilst some others respected the original character of the buildings, such as 
Table 5. Time of alteration of warehouses (Photos by Beser Oktay Vehbi).

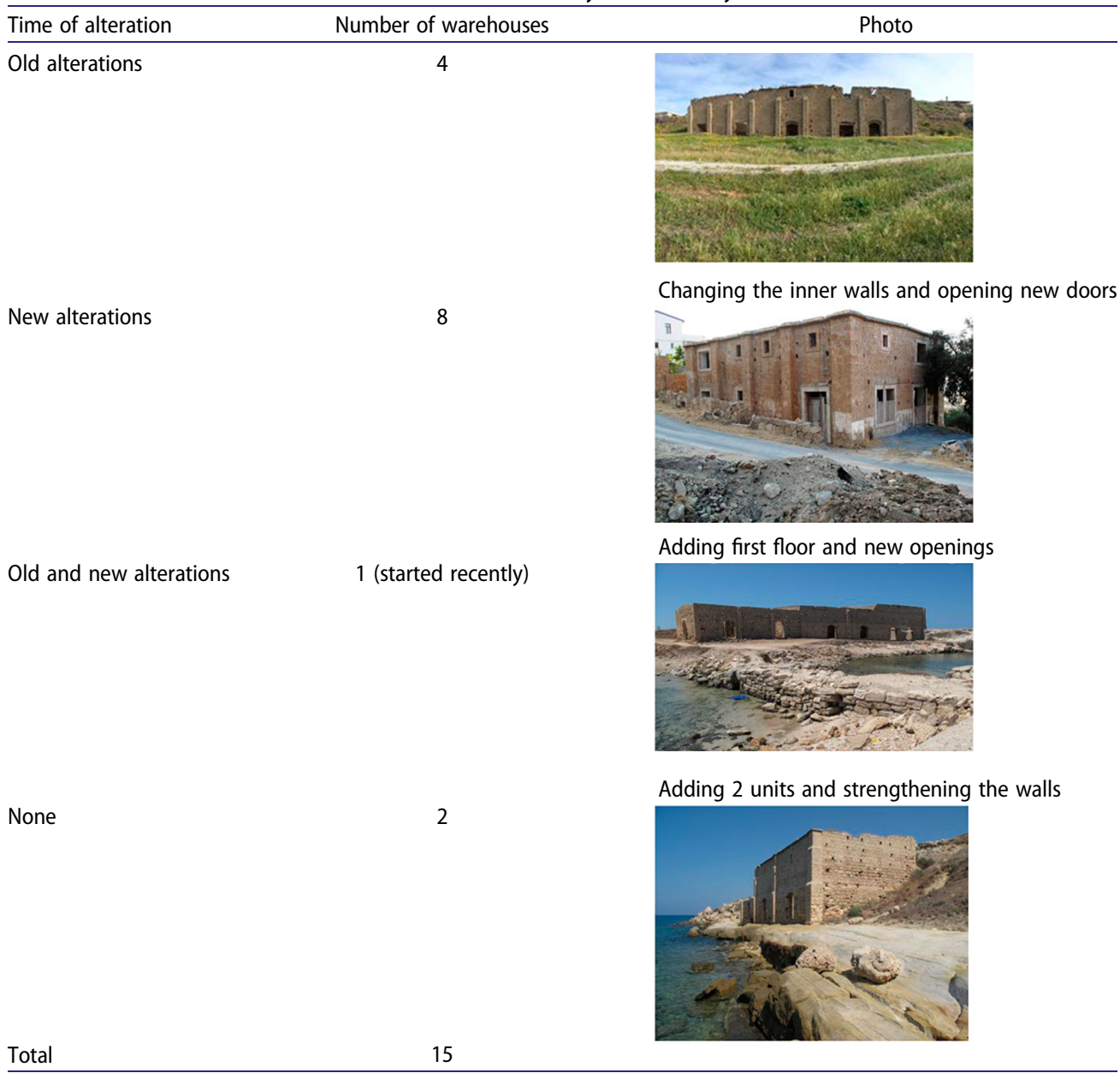

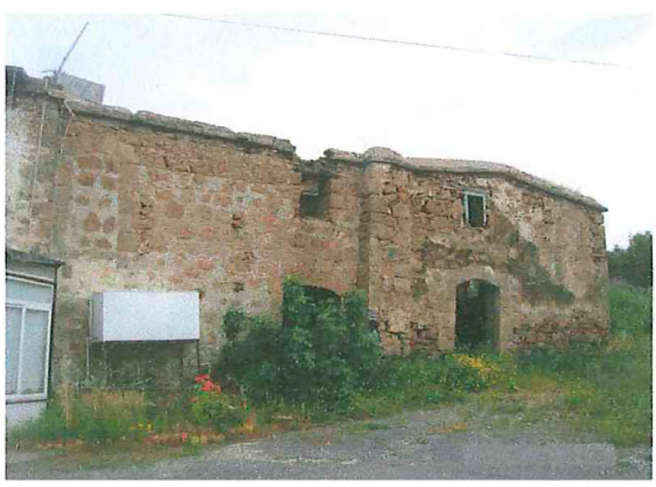

Before alteration (2011)

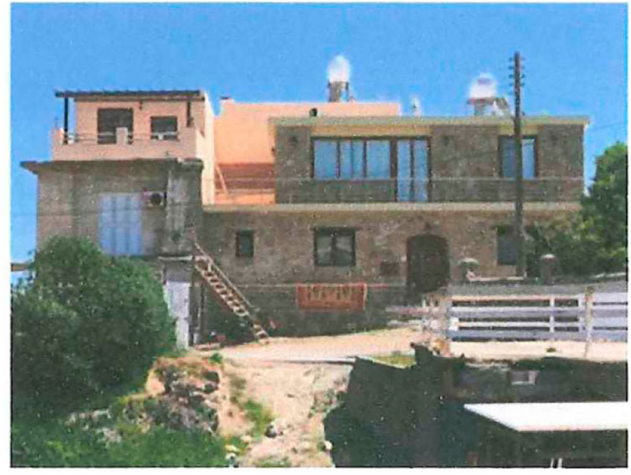

After alterations (2016)

Figure 8. Karşıyaka-house (Photos by Beser Oktay Vehbi). 


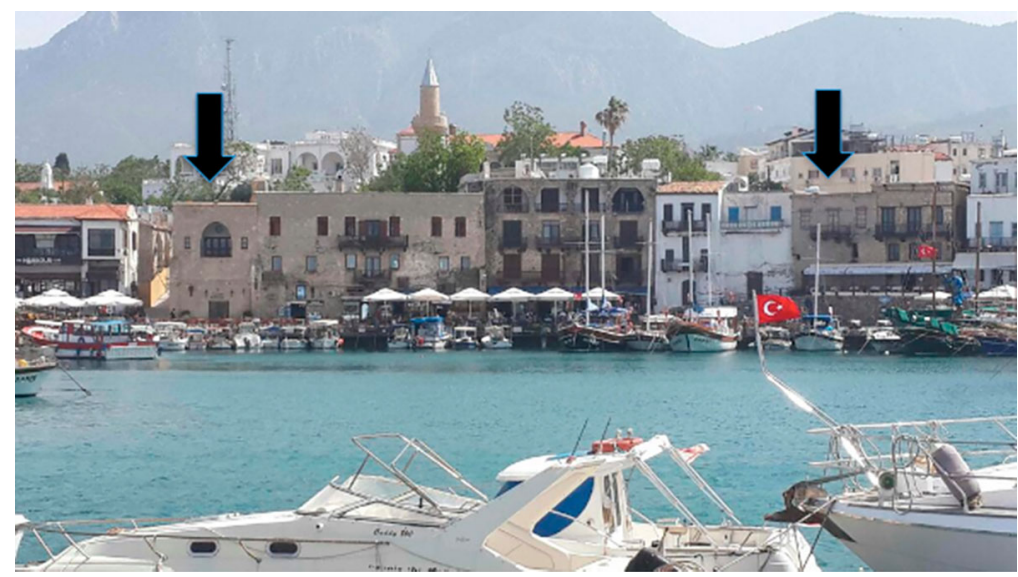

Figure 9. Warehouses at the Kyrenia harbour (Photo by Beser Oktay Vehbi).

the Kyrenia museum and Kyrenia cafe which have both contributed to the historical value of Kyrenia harbour for many years (Figure 9).

\subsection{Structural damage}

Structural damage in warehouses was analysed by assessing the safety of the warehouses in their current conditions. This enabled a clear differentiation of structural problems from a change in visual and spatial character which in turn gave the possibility of finding different types of solutions for these problems. Structural damage in carob warehouses can be categorized as:

- Structural damage due to alterations

- General structural problems.

\subsubsection{Structural damage due to alterations}

The number of warehouses subjected to alterations, which affected the safety of these buildings, is listed in Table 6.

The problematic alterations, which were made during the British period, contained various changes made in the openings and made additional rooms by changing the location of interior walls. These alterations caused changes to the roof structure, decreased the length of walls and caused harm to the walls. ${ }^{10}$

Table 6. Structural damage due to alterations.

\begin{tabular}{lc}
\hline Alteration type & Number of damaged structures \\
\hline Changing shape of openings & 4 \\
Closing some openings and making new oness & 7 \\
Making openings too large & 6 \\
Changing the location of inner walls & 2 \\
Additions of elements & 6 \\
Addition of a reinforced concrete slab & 2 \\
Use of inappropriate materials & 9 \\
\hline
\end{tabular}


Table 7. Types of alterations causing changes in visual and spatial character.

\begin{tabular}{lc}
\hline Alterations & Number of warehouses which have been changed \\
\hline Changing the shape of openings by adding timber lintels & 3 \\
Opening new and large doors & 4 \\
Closing small holes totally & 8 \\
Closing small holes from inside & 1 \\
Addition of a second floor & 4 (2 of them are satisfactory) \\
Addition of a reinforced concrete floor & 3 (1 caused partial collapse) \\
Addition of a balcony & 2 (1 of them is satisfactory) \\
Addition of a mezzanine floor & 4 \\
Addition of interior walls & 4 \\
Building adjacent structures & 2 \\
Raising the ground level & 1 \\
Adding an external stair & 1 \\
Adding a pitched roof & 1 \\
Cut stone decoration to corners & 2 \\
\hline
\end{tabular}

The problematic alterations that were made after the British period included making new openings, enlarging openings, creating additional space by building mezzanine floors and by adding a second floor and additional internal walls. A few of these alterations respect the character of the warehouses, whilst others changed the visual and spatial character of the buildings radically. However, some buildings that have been radically changed still have safe structures. Table 7 shows the types of alterations which led to changes in the visual and spatial characteristics of the warehouses.

According to the model the reasons for changes in the character of the buildings are alterations, private use, and abandonment.

\subsubsection{General structural problems}

The structural problems of carob warehouses are mainly through damage to:

(1) Roof structure

(2) Interior walls

(3) Exterior walls

(4) Foundations.

The roof coverings and beams of almost all of the warehouses were either severely damaged or had been replaced with reinforced concrete floors. Some of the stone arches and timber posts remained. There are collapsed parts and some major and minor/medium vertical cracks both in interior and exterior walls in some of the warehouses. Some warehouses also had minor/medium diagonal cracks and collapsed parts around their openings. It is accepted in this article that the cracks larger than $10 \mathrm{~mm}$ are major cracks and narrower ones are medium/minor cracks. Table 8 shows the number of warehouses in relation to the various types of structural damage.

According to the matrix of the model which lists architectural features in relation to structural damage, the major reasons for structural damage are:

- Poorly made alterations

- Abandonment

- Loss of roof which caused material deterioration 
Table 8. Types of structural damage.

\begin{tabular}{llc}
\hline Structural damage & & Number of warehouses \\
\hline Damage to roof structure & Damage to roof cover and beams & 11 \\
Damage to interior walls & Damage to timber posts or stone arches & 6 \\
& Collapsed parts & 2 (1 of them are large) \\
& Presence of major vertical cracks & 2 \\
Damage to exterior walls & Presence of medium/minor vertical cracks & 2 \\
& Collapsed parts & 4 (2 of them are large) \\
& Having too large openings & 6 \\
& Collapsed parts on two sides of doors & 2 \\
& Presence of major vertical cracks & 4 \\
Separation of interior and exterior walls & Presence of medium/minor vertical cracks & 4 \\
Damage to foundations due to the action of sea & Presence of diagonal cracks around openings & 3 \\
\hline
\end{tabular}

- Long span (approximately 20 meters) between the walls

- Insufficient thickness and long free standing height of walls

Some contemporary building codes do not allow stone walls more than 5.5 meters in length unless reinforced concrete (RC) tie-beams are used. They also define the maximum free standing height of walls as 3 meters. ${ }^{11}$

Since the Turkish building code, which is used in North Cyprus, does not include visual evaluation methods of masonry structures, and there are no local guidelines for this purpose, the guidelines of the Ministry of Home Affairs for the Government of India is used in this research in order to evaluate the level of damage in the warehouses. ${ }^{12}$

According to this method, the masonry buildings with some major and medium/minor cracks have moderate structural damage and buildings with considerably large collapsed parts in addition to major cracks have severe structural damage. Reconstruction is suggested as the best structural solution if there is severe damage and sufficient evidence to reproduce an earlier state of the fabric. ${ }^{13}$ Table 9 shows details for the determination of types of interventions for warehouses.

Table 9. Determination of types of interventions for the warehouses.

\begin{tabular}{|c|c|c|c|}
\hline Names of the warehouses & Number & Condition & $\begin{array}{l}\text { Need for } \\
\text { restoration }\end{array}$ \\
\hline $\begin{array}{l}\text { Kyrenia-museum } \\
\text { Kyrenia-Restaurant } \\
\text { Mersinlik-1 }\end{array}$ & 3 & Successfully restored & No need \\
\hline $\begin{array}{l}\text { Karşıyaka-residential, Karşıyaka- } \\
\text { hotel } \\
\text { Solonez } \\
\text { Karşıyaka-mountain }\end{array}$ & 4 & $\begin{array}{l}\text { Badly restored, radical change in visual and spatial } \\
\text { character }\end{array}$ & $\begin{array}{l}\text { Total } \\
\text { reconstruction }\end{array}$ \\
\hline $\begin{array}{l}\text { Esentepe-2 } \\
\quad \text { Mersinlik-2 }\end{array}$ & 2 & Severely damaged because of large collapsed parts & $\begin{array}{l}\text { Total } \\
\text { reconstruction }\end{array}$ \\
\hline $\begin{array}{l}\text { Yenierenköy } \\
\text { Kaplıca }\end{array}$ & 2 & Restoration started recently & Urgent need \\
\hline $\begin{array}{l}\text { Kayalar } \\
\text { Tatlısu-1 } \\
\text { Tatlısu-2 } \\
\text { Esentepe-1 }\end{array}$ & 4 & With minor or moderate damage & Urgent need \\
\hline
\end{tabular}




\subsection{Material deterioration}

There are numerous publications that deal with the causes of decay in historic buildings. ${ }^{14}$ Several deterioration processes have been observed in 10 of the warehouses.

Material problems of carob warehouses are categorized into two main headings; material loss due to erosion and deterioration due to the natural (e.g. vegetation, weathering and earthquake) and man-made factors. The sub categories are defined as loss of material (floor, plaster, etc.); loss of big particles of material from doors, windows, shutters, stone pieces; insects in wooden material; fungi in wooden/stone material; cracks in masonry due to biological accumulation; mortar fragmentation, detachment of mortar; moisture; erosion of stone; salt accumulation; animal attack (birds, dogs, etc.); rain penetration; rising damp; inappropriate material used for restoration. Table 10 shows the types material deformations that exist in warehouses.

Material loss due to erosion: Due to the location of the buildings, the existence of sea water and being placed towards the strong winter wind direction, the stone materials on the exterior walls have suffered from erosion. The lack of roof structure has also caused damage to internal walls. This type of material damage is not found on the four warehouses which are in use.

Loss of material as big broken particles: The main reason for this type of material damage is abandonment, being close to the sea, weather conditions and lack of roof structure. There are 11 warehouses that have lost some of their stone material, plaster, windows and doors shutters.

Cracks in masonry due to biological accumulation, vegetation: Both vertical and horizontal cracks due to vegetation were found in seven of the warehouses. Fig trees, which harm buildings with their strong roots, were growing inside the most of the warehouses.

Mortar fragmentation, detachment of mortar: Plants have damaged the mortar in six warehouses causing fragmentation and detachment. The existence of mortar fragmentation can encourage the generation of new cracks and enlarge the existing ones.

Signs of mould and insects: Signs of moisture and mould are easily identifiable especially on the north facing walls of seven of the warehouses. The damaged roof structure is the cause of the moisture penetration and associated mould. Climatic factors such as wind, solar radiation, rain and the proximity to the sea aggravated the salt problem. Internally rainwater ingress has led to some deterioration of timber posts and beams, and this has led to fungal attacks and the effects of termites and other wood insects.

Decay of timber: Timber lintels had more damage compared to timber posts and beams. The connection of the timber beams to the masonry walls is very poor. The post timbers were mostly in good condition but due to the lack of roof covering these elements were

Table 10. Types of material deterioration.

\begin{tabular}{lc}
\hline Material Deterioration & Number of Warehouses \\
\hline Loss of material (floor, plaster,) as layers parallel to the surface & 7 \\
Loss of material (door, window, shutters, stone) as big particles broken from the main material & 11 \\
Cracks in masonry due to biological accumulation, & 7 \\
Mortar fragmentation, detachment of mortar & 6 \\
Signs of moisture, mould and insects & 7 \\
Decay of timber & 5 \\
Inappropriate material usage for restoration & 4 \\
Salt accumulation & 7 \\
\hline
\end{tabular}


also damaged. Moisture caused the timber elements to become fragile and worn. Also, some of the timber joists in the roof system were fractured.

Inappropriate material usage for restoration: The use of inappropriate materials (brick, marble and $\mathrm{RC}$ ) led to a radical change in the buildings' appearance and caused extensive physical damage over time.

Salt accumulation: Stone material was damaged also due to salt and seawater spray on the surfaces of seven warehouses. Salt dissolved on the surfaces and penetrated the stonework.

\section{Suggestions for a holistic conservation}

Cultural heritage assets, which lost their original function due to physical and functional obsolescence, have to be restored and adapted to new functions. By having the holistic conservation approach not only the physical structure, the economic and social structure of the context will be improved. ${ }^{15}$

Accordingly, the comprehensive conservation approach should contain suggestions about the following issues:

- Restoration of the structure

- Interventions to solve material problems

- Taking initial steps towards development of adaptive reuse proposals. It should be kept in mind that the complete adaptive reuse projects of any building need further interventions regarding the functional and spatial needs of the suggested function.

\subsection{Restoration of the structures of warehouses}

The structural restoration attempts which can be considered for the structural problems of the warehouses are listed in Table $11 .^{16}$

The application in Figure 10 is designed specifically for these warehouses. To apply this detail, first drill two holes in the wall to put the steel bars in them. Then horizontal gaps should be formed in the mortar in order to place the tendons. The tendons should be connected to the two steel bars. Then cement mortar can be applied over the tendons into the mortar bed and grout should be injected into the drilled holes. On the other hand, the application of wire-mesh to the inside of the cracked walls is a common detail (Figure 11).

Figure 12 shows an additional retaining wall which takes place in front of the existing damaged/cracked one. These new retaining walls should be reinforced stone masonry with reinforced concrete vertical tie-beams hidden inside the stone wall. These tie-beams should be connected to the rocks with a horizontal tie-beam which is anchored to the rocks. The vertical tie-beams should also be connected to each other from the top with another horizontal tie-beam.

Figure 13 also shows a common application of injecting puzolanic lime based grout into the cracks of a stone wall with the help of some pipes placed into the cracks.

These are necessary processes of structural restoration of warehouses. Also a restoration proposal should be made for each carob warehouse in order to clarify the 
Table 11. Structural restoration attempts versus structural problems.

\begin{tabular}{|c|c|c|}
\hline $\begin{array}{l}\text { Structural } \\
\text { damage }\end{array}$ & & Solution \\
\hline \multirow{2}{*}{$\begin{array}{l}\text { Damage to roof } \\
\text { structure }\end{array}$} & Damage to roof cover and beams & Design and reconstruction using the original system \\
\hline & $\begin{array}{l}\text { Damage to timber posts or stone } \\
\text { arches }\end{array}$ & $\begin{array}{l}\text { Design and reconstruction of a reversible frame structure which } \\
\text { can carry the roof and also provide additional support to stone } \\
\text { walls. e.g.: There can be steel vertical elements, which are } \\
\text { connected to walls with the help of metal tendons inserted } \\
\text { into the walls. }\end{array}$ \\
\hline \multirow{4}{*}{$\begin{array}{l}\text { Damage to inner } \\
\text { walls }\end{array}$} & Collapsed small parts & Partial reconstruction \\
\hline & Presence of major vertical cracks & $\begin{array}{l}\text { Use of anchors containing steel bars and tendons (Figure 10), } \\
\text { injection of puzolanic lime based grout into the cracks, wire- } \\
\text { mesh and plaster application to the internal walls (Figure 11). }\end{array}$ \\
\hline & $\begin{array}{l}\text { Presence of medium } / \text { minor } \\
\text { vertical cracks }\end{array}$ & Injection of puzolanic lime based grout wherever necessary \\
\hline & Earth mortar in the interior walls & Partial replacement \\
\hline \multirow{8}{*}{$\begin{array}{l}\text { Damage to } \\
\text { exterior walls }\end{array}$} & Collapsed small parts & Partial reconstruction \\
\hline & Crack in a buttress & Partial reconstruction \\
\hline & Having too large openings & Partial reconstruction of related parts \\
\hline & $\begin{array}{l}\text { Collapsed parts on two sides of } \\
\text { doors }\end{array}$ & Partial reconstruction of related parts \\
\hline & Presence of major vertical cracks & $\begin{array}{l}\text { Use of anchors containing steel bars and tendons, injection of } \\
\text { puzolanic lime based grout into the cracks, wire-mesh and } \\
\text { plaster application from inside of the problematic walls }\end{array}$ \\
\hline & Crack in retaining walls & $\begin{array}{l}\text { Making an additional retaining wall in front of the existing one } \\
\text { (Figure 12) }\end{array}$ \\
\hline & $\begin{array}{l}\text { Presence of medium/minor } \\
\text { vertical cracks }\end{array}$ & $\begin{array}{l}\text { Injection of puzolanic lime based grout wherever necessary } \\
\text { (Figure 13) }\end{array}$ \\
\hline & $\begin{array}{l}\text { Presence of minor/medium } \\
\text { diagonal cracks around } \\
\text { openings }\end{array}$ & Injection of puzolanic lime based grout wherever necessary \\
\hline
\end{tabular}

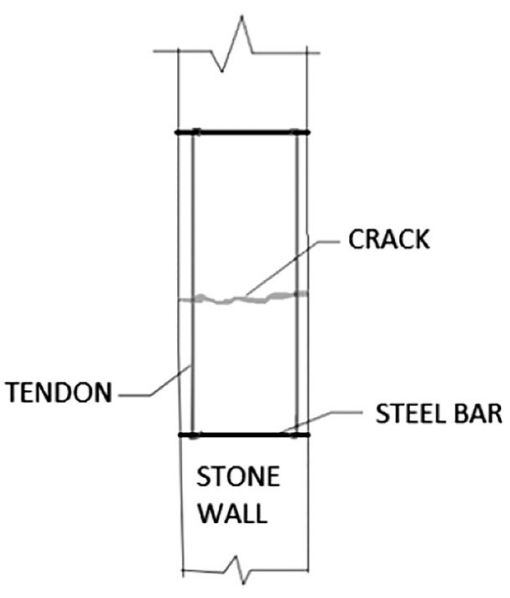

Figure 10. Wire-mesh and plaster application (Drawn by Yonca Hurol).

additional details which are needed because of the new function of the building. These projects should also ensure that the current service load requirements are met. 


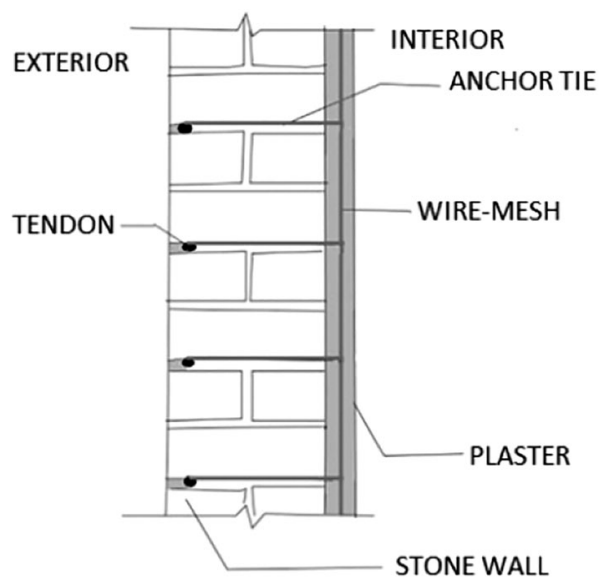

Figure 11. Use of anchors containing steel bars and tendons (Drawn by Yonca Hurol).

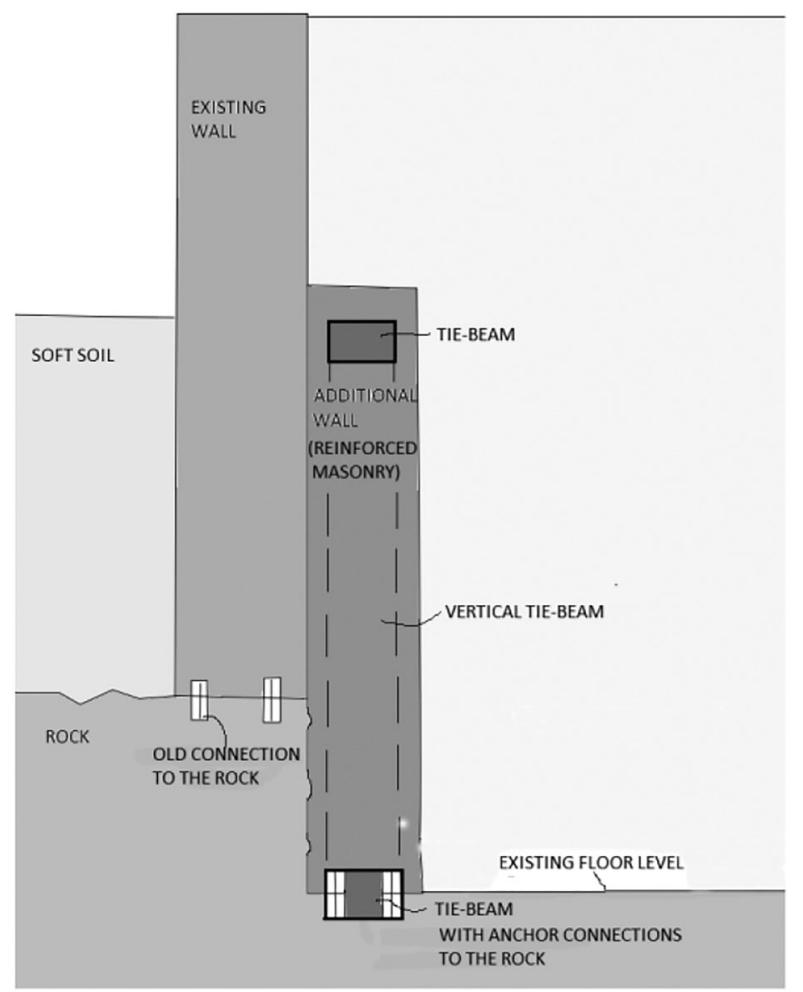

Figure 12. Partial section showing the existing and the additional retaining walls (Drawn by Yonca Hurol).

\subsection{Interventions to solve material problems}

For mitigating the material deterioration in the warehouses, the lost elements such as roof, floor, wall, shutters, should be replaced or repaired using traditional materials. ${ }^{17}$ Also any biological growth (mould, fungi, plants) has to be cleaned. Small plants and large trees 

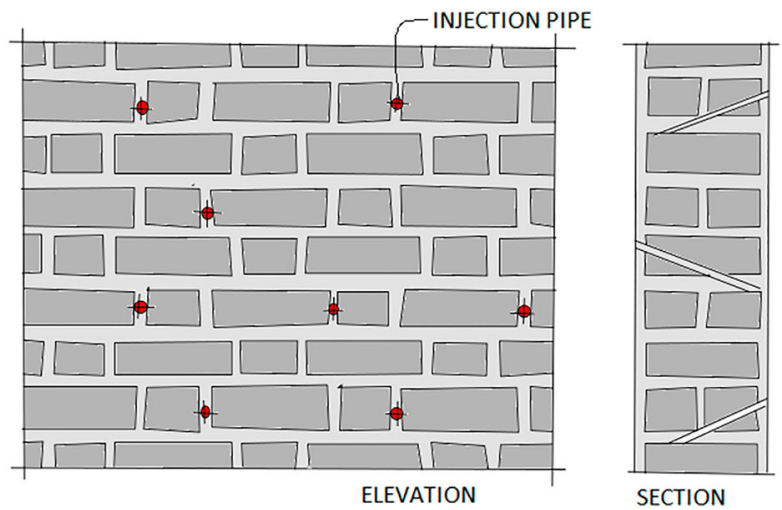

Figure 13. Injection of puzolanic lime based grout into the wall (Drawn by Yonca Hurol).

should be removed. In order to eliminate timber decay, maintenance or the replacement of timber beams and lintels is necessary. The timber elements should be treated with chemicals in order to prevent insect/termite attacks.

The salt in the walls should be cleaned. ${ }^{18}$ Stone pieces that are damaged should be replaced with similar stone pieces. Inappropriate materials should be removed. Stone surfaces should be cleaned from plaster patches and mould by using appropriate cleaning machines. ${ }^{19}$ The types, source and solutions for material deterioration are listed in Table 12.

\subsection{Adaptive reuse of warehouses: reinventing the carob-route}

The best and most sustainable way to preserve abandoned warehouses is to restore them and give them a new use that respects their historical and architectural characteristics and

Table 12. Causes of material deterioration and their solutions.

\begin{tabular}{|c|c|c|c|}
\hline Material Deterioration & $\begin{array}{l}\text { Number of } \\
\text { Warehouses }\end{array}$ & Causes of Decay & Solutions for its restoration \\
\hline $\begin{array}{l}\text { Loss of material (floor, plaster,) as } \\
\text { layers parallel to the surface }\end{array}$ & 7 & $\begin{array}{l}\text { Abandonment, } \\
\text { Vegetation, Natural } \\
\text { factors }\end{array}$ & Repair or replacement \\
\hline $\begin{array}{l}\text { Loss of material (door, window, } \\
\text { shutters, stone) as big particles } \\
\text { broken from the main material }\end{array}$ & 11 & $\begin{array}{l}\text { Abandonment, } \\
\text { Vegetation, Natural } \\
\text { factors }\end{array}$ & Repair or replacement \\
\hline $\begin{array}{l}\text { Cracks in masonry due to biological } \\
\text { accumulation, }\end{array}$ & 7 & $\begin{array}{l}\text { Abandonment, } \\
\text { Vegetation, Natural } \\
\text { factors }\end{array}$ & $\begin{array}{l}\text { Injecting puzolanic lime based } \\
\text { mortar }\end{array}$ \\
\hline $\begin{array}{l}\text { Mortar fragmentation, detachment of } \\
\text { mortar }\end{array}$ & 6 & $\begin{array}{l}\text { Abandonment, } \\
\text { Vegetation, Natural } \\
\text { factors }\end{array}$ & $\begin{array}{l}\text { Replacing/reconstructing the } \\
\text { mortar }\end{array}$ \\
\hline Signs of mould and insects & 7 & $\begin{array}{l}\text { Abandonment, Natural } \\
\text { factors }\end{array}$ & Biological cleaning \\
\hline Decay of timber & 5 & $\begin{array}{l}\text { Abandonment, Natural } \\
\text { factors }\end{array}$ & $\begin{array}{l}\text { Repairing or replacing the damaged } \\
\text { timber, using chemicals to } \\
\text { consolidate the timber. }\end{array}$ \\
\hline $\begin{array}{l}\text { Inappropriate material usage for } \\
\text { restoration \& wrong interventions }\end{array}$ & 4 & Man-made factors & $\begin{array}{l}\text { Repair or replacement by using } \\
\text { traditional material }\end{array}$ \\
\hline Salt accumulation & 7 & $\begin{array}{l}\text { Abandonment, Natural } \\
\text { factors }\end{array}$ & $\begin{array}{l}\text { Desalinization \& consolidation of } \\
\text { stone }\end{array}$ \\
\hline
\end{tabular}


allows regular maintenance. ${ }^{20}$ Although individual buildings must be assessed on their own merits during the conservation process, in respect of their relation to the past, their potential uses should be evaluated according to their values and meaning for their context. The conservation approach should also consider preserving and sustaining the cultural identity, historical and technological values of the Cypriot rural areas. Therefore, the new functions of the warehouses should be related to cultural tourism. Culture-led tourism in these rural villages can help to increase the economic value of the carob harvesting and the social well-being of the villagers along the north coast of the island, thus give rise to rural regeneration. ${ }^{21}$

With regard to the location of the buildings and their meaningful presence in the past as the central point of the carob harvest collection, any conservation attempt should consider the revival of the former carob way.

Since the access to some of them is difficult by land, sea transportation is essential to successfully revitalize these buildings. In line with this purpose, touristic tours are suggested along the northern coastline, which will visit the carob warehouses at each stop. The proposed carob routes should also be supported by Ministry of Tourism and Culture, local authorities and be included in the European Route of Industrial Heritage. The active participation of the local population should be encouraged to guarantee the regular maintenance of these buildings.

In order to assess most appropriate function for the warehouses, the spatial organization (morphological characteristics) of the building and extrinsic factors related to the external context (location, accessibility, ownership, landscape or available services, among others) have to be checked.

Regarding the holistic conservation and reinventing idea of carob route, general proposals are done for the new functions because a detailed further analysis is needed to suggest individual reuse for each building. In the current condition, only four of the 15 warehouses are in use. New functions can be suggested as technical museums, exhibition and workshop spaces, bookstores/libraries, restaurants, carob syrup processing spaces, carob museums and pensions, which are compatible with rural villages and cultural tourism.

\section{Case study: The Kayalar warehouse}

The Kayalar warehouse is located at the western end of the north coast and it contains two units of rectangular storage. Figure 14 shows some photos, plan and section of Kayalar warehouse. It was constructed in 1905 on the inclined area near the sea. The building is registered and it belongs to the Antiquities Department. It is not visible from the main vehicular road. The building currently has no function.

Different shapes of stones pieces are connected with cement mortar on the exterior walls and earth mortar on the interior walls. The walls are supported with three buttresses on the north façade. There are also buttresses on east and west facades. The corner buttresses are larger than the intermediate ones. The buttresses have equal height and they extend to the top of the building.

There were stone pointed arches in two bays of the structure. However, one of these arches has collapsed. This has created a structural problem for the interior wall because of the horizontal forces created by the remaining arch which is no longer balanced by the collapsed arch. The timber beams and roof coverings have completely disappeared. 

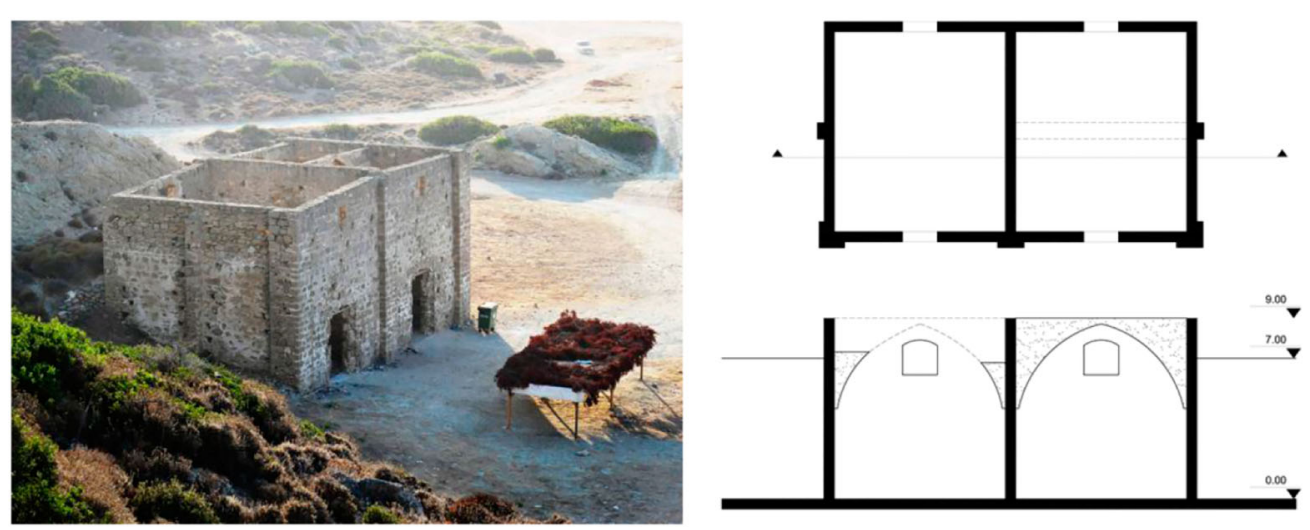

Figure 14. Photo, plan and section of Kayalar warehouse (Photo by Beser Oktay Vehbi, Figure drawn by Sanaz Nezhadmasoum and Beser Oktay Vehbi).

There were some alterations carried out during the British period on the Kayalar warehouse but this only entailed the widening of the two doors on the front façade. These doors had arches in their original forms but, they were changed into rectangular doors by adding timber lintels under the arches. The arches are still visible on the facade. This alteration caused damage on the two sides of these doors and some stone sections were displaced. There is also an inappropriate use of gypsum as mortar which caused damage especially around the two enlarged doors.

Unlike the other warehouses the small ventilation holes of this building are not distributed well on its façades. Since they are very close to each other and form approximately vertical lines, a medium vertical crack has occurred between them.

Stone erosion and salt crystallization has occurred on both external and internal walls. The building also has some minor cracks and detachment of mortar due to vegetation. The current state of the building is due to the destructive effects of weathering and the biological degradation of the stone, ageing of materials, which reduces its load bearing capacity. It needs urgent conservation.

The collapse of one arch and the presence of a medium vertical crack put this warehouse into the category of a moderately damaged structure. This is why restoration is proposed.

There is an urgent need to reconstruct the collapsed pointed arch in its original location in order to avoid the collapse of the interior wall and the remaining arch.

Since there are cracks and effects of deterioration present on the walls, it is suggested that horizontal and vertical steel tie-beams are installed inside the structure in order to support both the roof and the walls. These tie-beams can be connected to the walls with the help of drilled-in steel bars and grout which should be injected into the drilled holes. Roof lights could be considered within the roof structure in order to avoid opening new windows in the walls.

The masonry walls should be strengthened; this is especially required around the vertical crack. Metal bars and tendons can be placed at certain intervals to connect the two sides of this crack. It might also be necessary to close some of the small holes. It is also suggested to have a wire-mesh and plaster application on the internal face of this wall. Wall strengthening is also recommended by injecting puzolanic lime based grout into 
the cracks and wherever appropriate. Securing walls against rainwater is needed and gutters should be installed on the roof.

The damaged stone pieces on two sides of the enlarged doors should be removed and the missing pieces should be reconstructed with the same type of stone.

The earth mortar used in the interior wall should be partially replaced with a more durable and stronger type of mortar.

The warehouse has entirely lost its window frames, doors and shutters and the rubble stone floor covering partially. The small windows on top of each door still have their metal bars but not the timber shutters. Each rectangular unit has one rear window in the arch form with cut stone frame. The concrete surface, which covers half of the floor cover, should be removed. Missing elements such as wooden shutters need to be reproduced. The steel rods in the windows should be replaced and the existing ones should be repaired. After all physical interventions, the new function of the building should be evaluated and assigned according to the contextual, spatial and physical character and as well as its role within the carob route idea.

\section{Conclusion}

This article considered the British carob warehouses in Northern Cyprus and suggested the preservation of these heritage buildings and their re-integration into rural life.

The objective of this research was to assess the architectural and structural characteristics of these buildings. Due to time, a lack of awareness by the authorities of their value and inappropriate maintenance and alterations these buildings have become derelict and abandoned. The lack of systematic investigation and documentation, adequate funding and consistent technical standards has contributed to difficulties in their preservation and reuse. There are a few cases (three) that have had both structural and functional restoration. The others were subjected to the actions of weather and sea and ended up with severe or moderate damage to their structures.

A holistic conservation approach should first provide intensive physical interventions in order to solve the material and structural problems of the warehouses and follow the functional revitalization-reuse.

The major causes of the structural damage in the warehouses are material deterioration due to being close to the sea, abandonment and inappropriate alterations. If the three successfully restored warehouses are excluded, there remain a further 12 warehouses to be restored. Six of these need total reconstruction because of the presence of severe structural damage or the irreversibility of their condition without giving harm to their structures. The other six, which only have minor or moderate structural damage should be restored urgently. Material deterioration and structural problems of these 12 warehouses and their solutions can be seen in Tables 13 and 14 .

After this physical revitalization process, the warehouses need to be activated with proper functions. The adaptive reuse for any building has to avoid the destruction of the buildings' unity and cohesiveness. ${ }^{22}$ The changes should be minimal and reversible. Therefore, it is important to follow internationally accepted principles, laws and regulations not to damage the cultural significances of these structures.

One of the failures of previous individual re-use projects is that the warehouses were not considered as a part of the entire context of carob harvesting process which lacks a 
Table 13. Problems of 6 warehouses which need restoration (Photos by Beser Oktay Vehbi).

Name/Statue/Current use/Photo-Roof

Structure

Kayalar - Registered

Abandoned

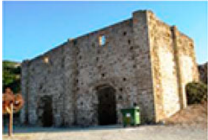

Stone pointed arches carrying timber

beams

Esentepe1 - Registered Abandoned

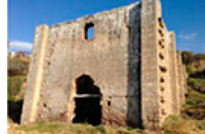

Stone pointed arches carrying timber beams

Tatlısu 1 (inland) - Registered Abandoned

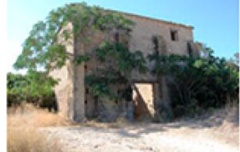

Timber post and beam

Tatlısu 2 - Registered Abandoned

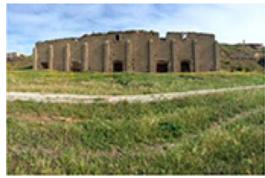

Timber and steel beams in four bays, timber post and beam in one bay
Material Damage

Structural damage

Solutions plaster),

Detachment of mortar, Moisture, Erosion

of stone, Salt accumulation Inappropriate material for the floor

Loss of material (roof, door, window shutters, floor, plaster)

Cracks in masonry,

Detachment of mortar

Fungi in wooden \& stone material

Moisture, Vegetation

Loss of material (roof, door, window shutters, floor, plaster),

Cracks in masonry,

Fungi in wooden/stone material,

Mould on the stone material,

Animal attack

Loss of material (roof, door, window shutters, floor, plaster)

Cracks in masonry,

Salt accumulation

Fungi in wooden/stone material,

Mould on the stone material

Animal attack
Loss of materials- (doors, windows, roof
Damage due to Alteration: additions of door lintels,

Damage in Roof structure, Damage

of a pointed arch

Medium cracks on the exterior walls, Inappropriate material used for the doors

Damage of roof structure and timber beams,

Presence of major cracks on exterior wall,

Presence of minor/medium cracks at exterior and interior walls, Cracks around openings

Damage due to alteration: having too large doors,

Damage of roof structure- posts,

beams, cover,

Minor cracks around openings

Closing some openings and making new openings (doors),

Presence of minor/medium vertical

and cracks in the inner walls,

Presence of collapsed parts around

openings and on the walls,

Minor vertical and diagonal cracks
Reconstruction of the roof, Replacement of missing parts on two sides of the doors, Use of anchors containing steel

bars and tendons for the major cracks,

Wire-mesh and plaster application to the cracked areas of interior walls,

Injection of puzolanic lime based grout into the cracks,

Cleaning \& Desalinization and consolidation of stone,

\section{Reconstruction of the roof,}

Use of anchors containing steel bars and tendons for the major cracks,

Wire-mesh and plaster application to the cracked areas of interior walls,

Injection of puzolanic lime based grout into the cracks, Cleaning the materials

Reconstruction of the missing roof and timber posts,

Replacement of missing parts on two sides of the doors, Injection of puzolanic lime based grout into the cracks, Cleaning the stone material

Replacement of missing parts on two sides of the doors, Reconstruction of the collapsed parts on top of the walls, Wire-mesh and plaster application to the cracked areas of interior walls,

Injection of puzolanic lime based grout into the cracks, Desalinization and cleaning and consolidation of stone 
Kaplıca - Registered Abandoned - Under restoration

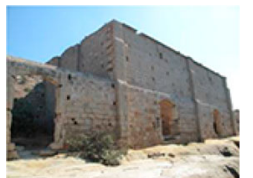

No sign left from roof structure

Yenierenköy-Registered, Abandoned, Under restoration

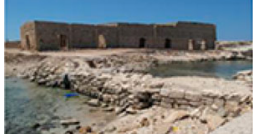

Timber post and beam and multiple arches supported by stone posts together,
Total damage in roof structure, Presence of collapse parts on two

sides of the doors,

Medium diagonal cracks around

retaining wall,

Medium vertical cracks in exterior

walls

Loss of material (roof, door, window shutters, floor, plaster),

Salt accumulation

Damage of roof cover and timber

beams, Opening new doors windows extending into the

Replacement of missing parts on two sides of the doors, Making a second retaining wall in front of the existing one,

Wire-mesh and plaster application to the cracked areas of interior walls,

Injection of puzolanic lime based grout into the cracks

(STARTED),

Desalinization and consolidation of stone

Medium cracks in the retaining wall
Reconstruction of roof cover and beams,

Making a second retaining wall in front of the existing one

(DONE),

Desalinization \& consolidation of stone 
Table 14. Problems of six warehouses which need total reconstruction (Photos by Beser Oktay Vehbi).

\begin{tabular}{|c|c|c|c|}
\hline Name/Statue/Current use/Photo-Roof Structure & Material Damage & Structural damage & Solutions \\
\hline $\begin{array}{l}\text { Karşıyaka Residential (on mountain) - Non- } \\
\text { registered - Under restoration }\end{array}$ & $\begin{array}{l}\text { Loss of material (floor, plaster) as layers parallel to the } \\
\text { surface, } \\
\text { Vegetation on the roof. }\end{array}$ & $\begin{array}{l}\text { Damage due to Alterations -Opening new and large doors } \\
\& \text { windows, } \\
\text { Adding RC mezzanine floor, Change of the location of } \\
\text { inner walls, alteration of roof structure, } \\
\text { Addition of stairs. }\end{array}$ & $\begin{array}{l}\text { Total } \\
\text { reconstruction }\end{array}$ \\
\hline \multicolumn{4}{|l|}{ 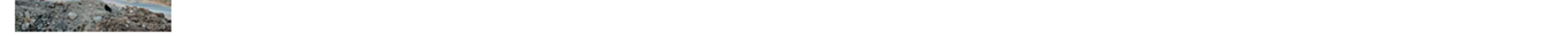 } \\
\hline $\begin{array}{l}\text { RC floor and roof } \\
\text { Karsiyaka Residential (near the sea) - Non } \\
\text {-registered - In use }\end{array}$ & $\begin{array}{l}\text { Loss of material- (floor, plaster, roof windows, doors } \\
\text { shutters) }\end{array}$ & $\begin{array}{l}\text { Damage due to Alterations- } \\
\text { Walls and buttresses were cut, }\end{array}$ & $\begin{array}{l}\text { Total } \\
\text { reconstruction }\end{array}$ \\
\hline \multirow{2}{*}{$\begin{array}{l}\text { RC floor and roof } \\
\text { Karsiyaka - hotel - Non-registered - Abandoned }\end{array}$} & & & \\
\hline & $\begin{array}{l}\text { Loss of doors, windows shutters, } \\
\text { Detachment of mortar, Cracks in masonry due to } \\
\text { vegetation, Moisture, Erosion of stone, } \\
\text { Salt accumulation, } \\
\text { Inappropriate material usage for restoration }\end{array}$ & $\begin{array}{l}\text { Damage due to Alterations- Addition of many inner walls, } \\
\text { Addition of a RC mezzanine floor and a RC roof, } \\
\text { Medium vertical crack in outer buttress, } \\
\text { Closing original openings and opening new and large } \\
\text { openings, Addition of attached structures. }\end{array}$ & $\begin{array}{l}\text { lotal } \\
\text { reconstruction }\end{array}$ \\
\hline
\end{tabular}


Esentepe 2 -Registered Abandoned

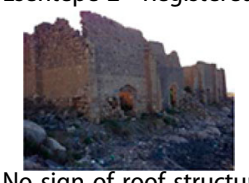

No sign of roof structure

Mersinlik 2 -Registered Abandoned

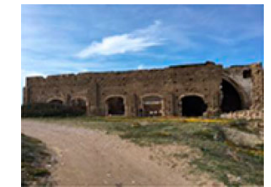

Stone pointed arches + multiple arches with stone
Loss of material- (walls, roof, door, window shutters, floor, plaster),

Fungi in wooden/stone material,

racks in masonry,

Detachment of mortar,

Moisture, vegetation, Salt accumulation

Loss of material (roof [partially], interior walls-partially, door, window shutters, floor, plaster),

Fungi in wooden/stone material,

Cracks in masonry, Detachment of mortar, Vegetation,

Salt accumulation
Damage to foundations due to sea

Damage due to alterations-

Total

Existence of large collapsed parts at interior and exterior

walls,

A corner buttress collapsed,

Buttress cracked into two vertically,

Minor cracks around windows,

Additions of timber door lintels,

Use of inappropriate materials and techniques for

maintenance,

Damage of the roof structure.

Damage due to alterations-

Pointed arches collapsed together with the additional

concrete roof,

Total

Small collapsed parts at exterior walls,

Presence of major vertical cracks on the interior and

exterior walls at corners,

Damage in roof cover and timber beams. 
holistic conservation approach. This study is suggested to consider the warehouses not only as individual buildings with their own merit but also have a group value as a chain of buildings that describe a former trading route. The proposed carob route will link these buildings both conceptually and physically with the sea and land routes.

Ignorance of the problems of carob warehouses could lead to their collapse or a change of their visual and spatial characteristics in the wrong hands very soon. The authorities responsible for their protection should gain an understanding of why the building has heritage status, and then activate a comprehensive conservation process for them. The restoration of these old industrial buildings, will create a living space in their locality which will remind present generations about their past glory and success.

\section{Notes}

1. N. B. Soyel and Z. Ahunbay, 'Kuzey Kıbrıs'taki Tarihi Su Degirmenlerinin Koruma ve Yeniden Kullanım Onerileri', ITU Dergisi/a, Mimarlik, Planlama, Tasarım 10, no. 1 (2011): 105-115; E. Rizopoulou-Egoumenidou, 'Corn Grinding Watermills in Cyprus: 18th - mid 20th centuries' (paper presented at 11th Symposium of the International Molinological Society, Portugal, September 25 - October 2, 2004); and Themos Demetriou, Restoration and Maintenance of Traditional Settlements (Nicosia: Cyprus Civil Engineers and Architects Association, 2003).

2. Hulya Yuceer and Beser O. Vehbi, 'Adaptive Reuse of Carob Warehouses in Northern Cyprus', Open House International 39, no. 4 (2014): 65-77.

3. Claude D. Cobham, Travels in the Island of Cyprus, A translation of G. Mariti's Viaggi per d'isola di Cipro vol 11769 (Nicosia: Cyprus Research Centre, 1909); and George Jeffery, A Description of the Historic Monuments in Cyprus-Studies in the Archaeology and Architecture of the Island Vol. I (Nicosia: Government Printing Office, 1918).

4. Barry S. Turner, The Story of the Cyprus Government Railway (London: Mechanical Engineering Publications. 1979); and Hugh Ballantyne, Cyprus Narrow Gauge (Sussex: Middleton Press, 2007).

5. Yuceer and Vehbi, 'Adaptive Reuse of Carob Warehouses in Northern Cyprus', 68.

6. Tuncer Bagıskan, 'Kıbrıs’n Kara Altını: Harnıp', Adres Dergisi Yenidüzen Gazetesi Eki 63 (2012): 15-21.

7. Eurocodes Committee- Scientific and Technical Chamber of Cyprus under a Ministry of Interior's Program, 'Eurocode 8 - Design of Structures for Earthquake Resistance - 2004 CYS, Annex to CYS EN 1998-1', http://www.cys.org.cy/images/public/eurocodes.

8. Printed at the Government Printing Office in Nicosia, 'The Cyprus Blue Books' contain statistics and other financial activities from Cyprus during the island's British rule (1878-1960) between years 1886 and 1946 .

9. Yonca Hürol, Hülya Yüceer, and Öznem Şahali, 'Building Code Challenging the Ethics Behind Adobe Architecture in North Cyprus', Science and Engineering Ethics 21, no. 2 (2015): 381-399.

10. Ministry of Public Works and Settlement Government of the Republic of Turkey, 'Seismic Performance Evaluation of Dual Reinforced Concrete Systems Design According to Turkish Seismic Code-2007', http://www.belgeler.com/blg/22lc/seismic-performanceevaluation-of-dual-reinforced-concrete-systems-design-according-to-turkish-seismic-code.

11. Ibid, 9-10.

12. Ministry of Home Affairs - Government of India, 'Guideline for Repair, Restoration and Retrofitting of Masonry Buildings in Earthquake Affected areas of Jammu and Kashmir-2006', http://nidm.gov.in/PDF/safety/earthquake/link5.pdf.

13. ICOMOS, 'The Burra Charter: The Australia ICOMOS Charter on Caring for Places of Cultural Significance - 1999', http://www.icomos.org/australia/burra.html. 
14. D. Honeyborne et al., 'Surface Treatments', in Conservation of Building and Decorative Stone, ed. J. Ashurst and F. G. Dimes (London and Boston: Butterworth-Heinemann, 1990), vol. 2, 155-84; Gabriele Grassegger, 'Decay Mechanisms of Natural Building Stones on Monuments: A Review of the Latest Theories', in Werkstoffe und Werkstoffprüfung im Bauwesen: Festschrift zum 60. Geburtstag von H.-W. Reinhardt, ed. C. U. Große (Stuttgart: IWB, 1999), 54-81; Bernard Feilden, Conservation of Historic Buildings (Oxford: Architectural Press, 2003); and B. J. Smith, G. H. Miguel, and S. McCabe, 'Understanding the Decay of Stonebuilt Cultural Heritage', Progress in Physical Geography 32, no. 4 (2008): 439-61.

15. B. Oktay, 'A Model for Measuring the Sustainability of Historic Urban Quarters: Comparative Case Studies of Kyrenia and Famagusta in North Cyprus' (PhD diss., Eastern Mediterranean University, 2005).

16. Andrew Smith and Thomas Redman, 'A Critical Review of Retrofitting Methods for Unreinforced Masonry Structures' (paper presented at EWB-UK Research Conference, Royal Academy of Engineering, Bristol, UK, February 20, 2009); and K. S. Thakkar and A. Pankaj, 'Seismic Evaluation of Earthquake Resistance and Retrofitting Measures of Stone Masonry Houses', 12 WCEE 2000, http://www.iitk.ac.in/nicee/wcee/article/0110.pdf.

17. ICOMOS, 'International Charter for the Conservation and Restoration of Monuments and Sites- 1964', http://www.icomos.org/charters/venice_e.pdf.

18. Eric Doehne and Cliford A. Price, Stone Conservation: An Overview of Current Research (Los Angeles: Getty Conservation Institute, 2011), 55-56.

19. C. M. Andrew, M. Young, and K. Tonge, Stone Cleaning: A Guide for Practitioners (Aberdeen: Historic Scotland and Robert Gordon University, 1994); N. Ashurst, Cleaning Historic Buildings (London: Donhead Publishing, 1994); Deborah Slaton and Kyle. C. Normandin, 'Masonry Cleaning Technologies-Overview of Current Practice and Techniques', in Cleaning Techniques in Conservation Practice, ed. K. C. Normandin and D. Slaton (Shaftesbury: Donhead, 2005), 7-33; and D. M. Worth, 'Book Review: Cleaning Techniques in Conservation Practice', APT Bulletin 38, no 1 (2007): 68.

20. W. Morris, 'Manifesto of the Society for the Protection of Ancient Buildings - 1877' http:// www.spab.org.uk/what-is-spab-/the-manifesto/.

21. Town Planning Office, Ministry of Internal Affairs, Turkish Republic of Northern Cyprus, 'National Physical Plan- 2012', http://ulkeselfizikplan.spd.gov.ct.tr/icerik.php?id=2

22. ICOMOS, 'The Burra Charter: The Australia ICOMOS Charter on Caring for Places of Cultural Significance - 1999’.

\section{Notes on Contributors}

Beser Oktay Vehbi trained as an architect and then specialized in urban design. She is working as a full time member of staff, teaching architecture, urban design and conservation at the Eastern Mediterranean University. She advised the Supreme Council of Immoveable Antiquities and Monuments in Northern Cyprus for five years (2005-2011) as Eastern Mediterranean University Representative. Her publications are related to conservation of historic urban and rural areas, sustainable urban conservation and adaptive reuse.

Hiilya Yuceer is an architect, and specialized in conservation during her studies at the Middle East Technical University in Ankara and experience in private offices, governmental institutions in Turkey and research in English Heritage and ICCROM. In 2010, she acted as team coordinator for the UNDP-PFF project 'Cultural Heritage Data Collection' in Famagusta during her employment at the Eastern Mediterranean University. She currently works at Adana Science and Technology University which she joined in September 2013.

Yonca Hurol is a Professor at the Department of Architecture, Eastern Mediterranean University, North Cyprus. She has been teaching structure to students of architecture for more than 30 years. She worked in Middle East Technical University, Gazi University and Eastern Mediterranean University. She has published many articles in the areas of her research interest, structures in architecture, earthquake architecture, ethics and architecture. 